\title{
Integrated Management of Meloidogyne Incognita Infecting Broadbean by Extracts of Dried Leaf Powder of Medicinal Plants or Yeast Singly or Mixed with Yeast as Foliar Spraying Applications under Greenhouse Conditions
}

\author{
El-Sherif, A. G. *; Nour El-Deen**, A.H; Gad, S. B.*; El-Nahas, H. A*. \\ *Nematology Res. Unit, Agric. Zool. Dept, Fac. Of Agric., Mansoura Univ. Dk. Egypt. \\ ** Biology Dept., Fac of Science, Taef University, Saudi Arabia.
}

\begin{abstract}
The influence of five medicinal plant dried leaf powder extracts i.e. cinnamon, lupine, garlic, onion and wormwood; and yeast extract singly or mixed with yeast extract as foliar spraying applications in comparison with oxamyl on $M$. incognita infecting broadbean cv. Sakha 1 plant growth response and nematode criteria under greenhouse conditions $\left(19 \pm 3^{\circ} \mathrm{C}\right)$. Results indicated that all tested applications significantly improved broadbean plant growth characters and reduced nematode parameters as well. Moreover, all tested concomitant treatments significantly gave better results than single one did. Of the single treatments, yeast extract showed the maximum values in ameliorating plant length, total plant fresh weight and shoot dry weight followed by garlic, onion and then cinnamon, whereas lupine plant powder extract gave the minimum values for the same parameters, respectively. Meanwhile, plant received yeast plus garlic achieved the maximum results in ameliorating broadbean growth parameters followed by yeast plus onion extracts, respectively. Moreover, yeast extract overwhelmed other single treatments in suppressing nematode population $(74.7 \%)$, whereas lupine extract showed the least value of this parameters $(36.9 \%)$, respectively. Meanwhile, pots received yeast mixed with garlic overwhelmed other integrated treatments in this respect. Chemical analysis of $\mathrm{N}, \mathrm{P}, \mathrm{K}$, total phenol and total chlorophyll in this study was recorded and discused.
\end{abstract}

Keywords: Broadbean plant growth, Integrated management Meloidogyne incognita, medicinal plant extracts, yeast, oxamyl

\section{Introduction}

The Fabaceae, commonly known as the legume, pea, or bean family, are a large and economically important family of flowering plants. The group is the thirdlargest land plant family with 730 genera and over 19,400 species. Plants of this family are found throughout the world, growing in many different environments and climates. In addition, poor target specificity of chemicals pose environmental and human toxicity hazards (Barker et al., 1998). Therefore, environmentally friendly alternatives are required for nematode control. Biological control is one possible safe alternative to pesticides for disease management, and is likely to be free from 
toxic residual effects. There are numerous microbial antagonists of root-knot nematodes and their application resulting in significant decrease in the nematode populations (Khan, 2007). The approach of combining biological control agents to manage various soil borne pathogens including plant parasitic nematodes has been investigated extensively (Hojat et al., 1998, Duponnis et al., 1999 and Al-Ghnam, 2011). Therefore, the present investigation was conducted in order to study the integrated management of $M$. incognita infecting broad bean cv Sahkia 1 using five dried powder of medicinal plants extracts singly or mixed with yeast as foliar spraying applications in comparison with oxamyl under greenhouse conditions at $19 \pm 3^{\circ} \mathrm{C}$.

\section{Material and Methods}

Nematode stock culture, propagations and preparing nematode inoculum:

To collect and determine the inocula of Meliodogyne incognita eggs; $M$. incognita was previously identified according to Taylor et al., (1955). Infected root systems with heavy eggmasses of $M$. incognita of various growing coleus, Coleus blumei plants, grown in $25 \mathrm{~cm}$-diam plastic pots filled with sterilized loamy sandy soil (1:1) (v:v) at the Nematology Res. Unit, Agricultural Zoology Department, Fac. of Agriculture, Mansoura university, Egypt, were well washed and cleaned by running tap water, then placed in a plastic container with enough solutions of $1.0 \%$ $\mathrm{NaOCl}$ following the method of Hussey and Barker(1973). Eventually, the number of eggs per unit volume of water was counted and then inoculated plants directly with eggs according to the design of each experiment of this work which was carried out at the greenhouse of Nematological Research Unit.

Integrated management of $M$. incognita infecting broad bean cv Sahkia 1 using extracts of five dried powder of medicinal plants and yeast extract singly or mixed with yeast as foliar spraying applications in comparison with oxamyl under greenhouse conditions at $19 \pm 3^{\circ} \mathrm{C}$.

Greenhouse experiment was conducted to study the impact of five medicinal plant powder extracts as foliar spray application i.e. wormwood, cinnamon, lupine, onion, garlic and yeast extract solely or mixed with yeast extract in comparison with oxamyl at the recommended dose against $M$. incognita infecting broadbean (Vicia faba) $\mathrm{cv}$. Sakha 1 as a susceptible host at $19 \pm 3^{\circ} \mathrm{C}$. Three seeds of broadbean were separately sown in each plastic pot (10-cm-diam), filled with $900 \mathrm{~g}$ steam-sterilized clay sand (1:1) (v: v). Two weeks later after seeds germination, seedlings were thinned into one seedling / pot. At this time, forty four seedlings were separately inoculated with 1000 eggs of $M$. incognita plus another four broadbean seedlings left without nematode and any treatment to serve as a check. Meanwhile, each plant extract was separately prepared by dissolving $10 \mathrm{~g}$ of dried leaf / liter of distilled water, then $15 \mathrm{ml}$ of each extract was separately sprayed on eight seedlings except that of yeast extract with four seedlings only. This process of foliar 
spraying was repeated two times each at seven days intervals. In the meantime, four seedlings out of eight ones per wormwood, cinnamon, lupine, onion, garlic, were separately sprayed with yeast extract as integrated ones. This process was also repeated twice at seven days intervals. Soil surface of each treated plastic pot was covered with aluminum foil during spraying process to avoid spilling of the sprayed material. At the same time, four brodbean seedlings with nematode received oxamyl at the recommended dose $(0.3 \mathrm{ml} /$ seedling $)$ only and another four seedlings with nematode only were also included. Each treatment was replicated four times. Treatments were as follows:

1. $\mathrm{N}+(15 \mathrm{ml} /$ plant $)$ Cinnamon,

2. $\mathrm{N}+(15 \mathrm{ml} /$ plant $)$ Lupine,

3. $\mathrm{N}+(15 \mathrm{ml} /$ plant $)$ Garlic,

4. $\mathrm{N}+(15 \mathrm{ml} /$ plant $)$ Onion,

5. $\mathrm{N}+(15 \mathrm{ml} /$ plant $)$ yeast,

6. $\mathrm{N}+(15 \mathrm{ml} /$ plant $)$ wormwood,

7. $\mathrm{N}+(15 \mathrm{ml} /$ plant $)$ Cinnamon+ $+(15 \mathrm{ml} /$ plant $)$ yeast,

8. $\mathrm{N}+(15 \mathrm{ml} /$ plant $)$ Lupine+ $(15 \mathrm{ml} /$ plant $)$ yeast,

9. $\mathrm{N}+(15 \mathrm{ml} /$ plant $)$ Garlic $+(15 \mathrm{ml} /$ plant $)$ yeast,

10. $\mathrm{N}+(15 \mathrm{ml} /$ plant $)$ Onion+ $+(15 \mathrm{ml} /$ plant $)$ yeast,

11. $\mathrm{N}+(15 \mathrm{ml} /$ plant $)$ wormwood $+(15 \mathrm{ml} /$ plant $)$ yeast,

12. $\mathrm{N}+\mathrm{Oxamyl}$,

13. $\mathrm{N}$ alone and

14. Plant free of $\mathrm{N}$ and any treatment.

Plastic pots were arranged in a completely randomized design. Pots were watered with tap water as needed. Plants were harvested 45 days after nematode inoculation. Data dealing with plant length, fresh root \& shoot weights were determined and recorded. Dry shoot weight was also estimated and recorded. Nematodes were extracted from $100 \mathrm{~g}$ soil using sieving and modified Baermannpan technique (Goodey, 1957). The nematode suspension were examined using a Hawksely counting slide with an anatomy microscope to quantify the juveniles number, then calculated the juveniles number per pot and recorded.

The infected roots were stained in acid fuschin (Byrd, et al., 1983), washed in tap water and placed in pure cold glycerin. After clearing, numbers of galls, eggmasses, females, and endo-parasitic forms (development stages) were determined with the aid of a stereo microscope and recorded. 
Concerning $\mathrm{N}, \mathrm{P}$ and $\mathrm{K}$ determination, $0.2 \mathrm{~g}$. of dry weight of shoot was subjected to chemical analysis as follows: total nitrogen content was determined according to the improved kjeldahl method modified by distilling the ammonia into saturated boric acid solution and titration with $0.1 \mathrm{Nacl}$ standard. Total phosphorus was colorimetrically determined using the chlorostannous reduced Molybdophosphoric blue colour method, while total potassium was flam photometry estimated as described by Jakson (1967). Chlorophyll content was spectrophotometrically measured in leaves of the harvested plant using Fadeel's method (1962). Chlorophyll concentrations were calculated according to Wellburn and Lichtenthaler (1984). The content of chlorophyll was then expressed in $\mathrm{mg} / \mathrm{g}$. fresh weight of leaves. Root gall index (RGI) and egg-mass index (EI) were determined according to the scale given by Taylor and Sasser (1978) as follows: $0=$ no galls or egg-masses, $1=1-2$ galls or egg-masses, $2=3-10$ galls or eggmasses, $3=11-30$ galls or egg-masses, $4=31-100$ galls. Data were subjected to analysis of variance (ANOVA) (Gomez and Gomez, 1984), followed by Duncan's multiple range tests to compare means (Duncan, 1955).

\section{Results and Discussion}

Data in Table (1) summarize the influence of five medicinal plant as dried leaf powder extracts i.e. cinnamon, lupine, garlic, onion and wormwood and yeast extract singly or mixed with yeast extract as foliar spraying applications in comparison with oxamyl on response of broad bean cv. Sakha 1 infected with M. incognita under greenhouse condition $\left(19 \pm 3^{\circ} \mathrm{C}\right)$. Results indicated that all tested applications significantly improved broad bean plant growth characters. Moreover, all tested concomitant treatments significantly gave better results than single one did. Of the single treatments, yeast extract showed the maximum values in ameliorating plant length, total plant fresh weight and shoot dry weight with values of $63.5,27.5$ and $28.9 \%$ followed by garlic extract with values of 58.1, 26.8 and $16.5 \%$, onion extract $(48.1,24.2$ and $8.2 \%)$ and then cinnamon extract $(50.0,20.3$ and $4.0 \%$ ) whereas wormwood extract gave the moderately values of $40.4,15$ and $16.5 \%$ for the same plant growth criteria, whilst lupine plant powder extract gave the minimum values for the same plant growth parameters that averaged 40.4,10.5 and $2.6 \%$ respectively, comparing to nematode alone (Table 1 ). Moreover, oxamyl as a nematicide at the recommended dose achieved a considerable percentage increase values of $61.5,73.9$ and $34.5 \%$ for plant length, total plant fresh weight and shoot dry weight, respectively, comparing to nematode alone. Meanwhile, among the tested concomitant treatments plant received garlic plus yeast extracts achieved the maximum results in ameliorating broad bean growth parameters with values of 88.5, 88.9 and $37.3 \%$ for plant length, total plant fresh weight and shoot dry weight, followed by onion plus yeast extracts $(63.5,75,35.9 \%)$. In addition, similar trend was also recorded with the combinations of yeast plus cinnamon as well as yeast plus wormwood with values that averaged 57.7, 73.9 and $35.9 \%$; and 53.8, 66.7 
and $35.9 \%$ for the same plant growth characters, respectively, comparing to nematode alone. However, plant received treatment containing foliar spraying yeast extract plus lupine as applied in this work showed the minimum values for the same plant growth criteria that averaged $51.9,52.9$ and $34.5 \%$, respectively, comparing to nematode alone (Table 1). It is worthy to note that oxamyl as systemic nematicide gave equal values to the application cinnamon plus yeast extracts in total plant fresh weight $(73.9 \%)$ and shoot dry weight (35.9\%) respectively, comparing to nematode alone.

Data in Table (2) represent the impact of five medicinal plant extracts i.e. cinnamon, lupine, garlic, onion, warmwood applied singly or integrated with yeast extract as foliar spraying applications in comparison with oxamyl at full dose infected with $M$. incognita on nematode reproduction under greenhouse condition at $19 \pm 3^{\circ} \mathrm{C}$. In general, all tested materials obviously reduced nematode parameters to great extent. Among the single treatment, yeast extract overwhelmed other single treatments in suppressing nematode population $(74.7 \%)$, followed by onion extract $(69.0 \%)$, then those of garlic $(47.2 \%)$, wormwood $(44.4 \%)$ and cinnamon $(40.3 \%)$, whereas lupine extract showed the least value of nematode population $(36.9 \%)$ comparing to nematode alone, respectively. Moreover, pots received yeast extract alone achieved the maximum result in reducing this nematode character $(74.7 \%)$ and even exceeded some of the concomitant applications in suppressing final nematode population such as yeast plus wormwood extract $(63.1 \%)$, cinnamon + yeast extract $(73.8 \%)$ and lupine + yeast extract $(51.2 \%)$, respectively, comparing to nematode alone (Table 2). Of the tested concomitant applications, pots received yeast extract mixed with garlic extract as foliar spraying application as applied in this work, overwhelmed other integrated treatments. For instance garlic + yeast extracts gave the maximum percentage of reduction in final nematode population of M. incognita on broadbean cv. Shakha 1 with value of $80 \%$, followed by yeast + onion extracts $(75.9 \%)$ and that of cinnamon + yeast extracts $(73.8 \%)$, respectively, whereas the lowest value of final nematode population was recorded by lupine + yeast extracts treatment that is amounted to $51.2 \%$, comparing to nematode alone (Table 2). Meanwhile, oxamyl as a nematicide at the full recommended dose ranked first in this investigation in suppressing nematode population with value of $81.7 \%$ a which can be considered as on par with that of garlic + yeast extracts treatment $(80.0 \%)$, comparing to nematode alone. Rates of $M$. incognita reproduction were drastically diminished in treatments of single or concomitant of tested plant powder extracts as foliar spraying applications. Such affects ranged between 1.05 or 0.33 vs 1.67 in nematode alone, respectively. Yeast extract application had the lowest rate of reproduction $(0.42)$ at the single treatments, while that of lupine extract had the highest one (1.05). On the other hand, similar trend occurred in the concomitant applications, where treatment of yeast + garlic extracts showed the lowest rate of nematode reproduction (0.33), whereas treatment of lupine + yeast extracts had the highest one (0.82) (Table 2). Likewise, significant results were also noticed between 
El-Sherif, A. G. et al., ......

Egypt. J. Agronematol., Vol. 13, No. 2, (2014) 
Table (1): Plant growthresponse of brogdbean or. Sakha1 as affected by folia spraying of five medicinal plant extracts and yeast extract solely a followed with yesst extract in comparis on with oxamyl under the stress of Meloidogyne incognita Infection in Greenhouse Condition at $19 \pm 3^{\circ} \mathrm{C}$.

\begin{tabular}{|c|c|c|c|c|c|c|c|c|c|c|}
\hline \multirow{3}{*}{ Treatments } & \multicolumn{10}{|c|}{${ }^{\text {} P}$ Plant grouth response } \\
\hline & \multicolumn{2}{|c|}{$\begin{array}{l}\text { Length } \\
(\mathrm{cm})\end{array}$} & \multirow{2}{*}{$\begin{array}{c}\text { Total plant } \\
\text { length } \\
\text { (cm) }\end{array}$} & \multirow[t]{2}{*}{ Inc.\% } & \multicolumn{2}{|c|}{$\begin{array}{c}\text { Fresh weight } \\
\text { (g) }\end{array}$} & \multirow{2}{*}{$\begin{array}{l}\text { Total plant } \\
\text { - F. wt (g) }\end{array}$} & \multirow{2}{*}{\multicolumn{2}{|c|}{$\begin{array}{l}\text { Shoot dry } \\
\% \text { weight } \\
\text { (g) }\end{array}$}} & \multirow{2}{*}{ Inc. \% } \\
\hline & Shoot & Root & & & Shoot & Root & & & & \\
\hline Cinnamon & $53 \mathrm{e}$ & $25 b$ & $78 \mathrm{~g}$ & 50 & $14.1 \mathrm{~g}$ & $4.3 \mathrm{e}$ & $18.4 \mathrm{~h}$ & 20.3 & $7.50 \mathrm{~d}$ & 4.0 \\
\hline Lupine & $48 \mathrm{~h}$ & $25 b$ & $73 i$ & 40.4 & $14.0 \mathrm{~g}$ & $2.9 f$ & $18.9 \mathrm{j}$ & 10.5 & $7.40 \mathrm{e}$ & 2.6 \\
\hline Garlic & $57.2 b$ & $25 b$ & $822 d$ & 58.1 & $14.9 f$ & $4.9 d$ & $19.4 f$ & 26.8 & $8.40 \mathrm{bc}$ & 16.5 \\
\hline Onion & $48 \mathrm{~h}$ & $29 a$ & $7 \mathrm{~h}$ & 48.1 & $18.5 \mathrm{e}$ & $2.5 \mathrm{~g}$ & $19.0 \mathrm{~g}$ & 242 & $7.80 \mathrm{c}$ & 8.2 \\
\hline Yeast & $55 \mathrm{c}$ & $30 \mathrm{a}$ & $85 b$ & 83.5 & $14.6 \mathrm{f}$ & $4.9 \mathrm{~d}$ & $19.5 f$ & 27.5 & $9.30 \mathrm{~b}$ & 28.9 \\
\hline Wormwood & $50 \mathrm{~g}$ & $23 \mathrm{c}$ & $73 i$ & 40.4 & $14.8 f$ & $2.8 \mathrm{f}$ & $17.6 \mathrm{i}$ & 15.0 & $8.40 \mathrm{e}$ & 18.5 \\
\hline Cinnamon + Yeast & $52 f$ & $30 \mathrm{a}$ & $82 d$ & 57.7 & $21.4 \mathrm{~b}$ & $5.2 \mathrm{c}$ & $28.6 \mathrm{~b}$ & 73.9 & $9.80 \mathrm{a}$ & 35.9 \\
\hline Lupine + Yesst & $54 d$ & $25 b$ & $79 f$ & 51.9 & $19.2 \mathrm{~d}$ & $42 \mathrm{e}$ & $23.4 \mathrm{e}$ & 52.9 & $9.70 \mathrm{~b}$ & 34.5 \\
\hline Garlic + Yeast & $88 \mathrm{a}$ & $30 \mathrm{a}$ & $\$$ a & 88.5 & $23.5 \mathrm{a}$ & $5.4 \mathrm{c}$ & $28.9 \mathrm{a}$ & 88.9 & $9.90 \mathrm{a}$ & 37.3 \\
\hline Onion + Yesst & 550 & $30 \mathrm{a}$ & $85 b$ & 83.5 & $20.6 \mathrm{c}$ & $6.2 b$ & $28.8 \mathrm{~b}$ & 75.0 & $9.80 \mathrm{a}$ & 35.9 \\
\hline Wormwood + Yeest & $55 \mathrm{c}$ & $25 b$ & $80 \mathrm{e}$ & 53.8 & $20.5 \mathrm{c}$ & $5.0 \mathrm{C}$ & $25.5 \mathrm{~d}$ & 68.7 & $9.80 \mathrm{a}$ & 35.9 \\
\hline Oxamyl & $53.9 \mathrm{~d}$ & $30.1 \mathrm{a}$ & $84.0 \mathrm{C}$ & 81.5 & $19.1 \mathrm{~d}$ & $7.5 \mathrm{a}$ & $28.6 \mathrm{C}$ & 73.9 & $9.80 \mathrm{a}$ & 35.9 \\
\hline$N$ alone & $34.0 \mathrm{i}$ & $18.0 \mathrm{e}$ & $52 \mathrm{k}$ & -.. & $13.5 \mathrm{~h}$ & $2.8 f$ & $15.3 k$ & $\cdots$ & $7.21 f$ & -.. \\
\hline Plant free of any treatment and $\mathrm{N}$ & $50 \mathrm{~g}$ & $20 d$ & $70 \mathrm{j}$ & 34.6 & $14.5 f$ & $2.0 \mathrm{~h}$ & $18.5 \mathrm{j}$ & 20.9 & $7.3 \mathrm{e}$ & 1.2 \\
\hline LSD 0.05 & 0.58 & 0.001 & 0.02 & $\cdots$ & 1.24 & 1.14 & 2.23 & $\cdots$ & 3.25 & $\cdots$ \\
\hline
\end{tabular}

$N=1000$ eggs of IM. Incognits.

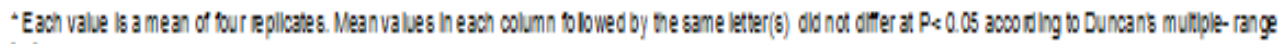
test. 
root galls indices of all tested plant extracts and nematode alone, since they ranged from 2 to 4 for garlic + yeast extracts, and lupine extract respectively vs 5 for nematode alone. Similar results was observed with the eggmasses indices on roots with range between 0 to 3 for garlic + yeast extracts and most of single treatments vs 5 for nematode alone, respectively (Table 2). Moreover, regression analysis between tested treatments vs nematode reproduction factor gave $R^{2}$ value 0.0062 (Fig. 1).

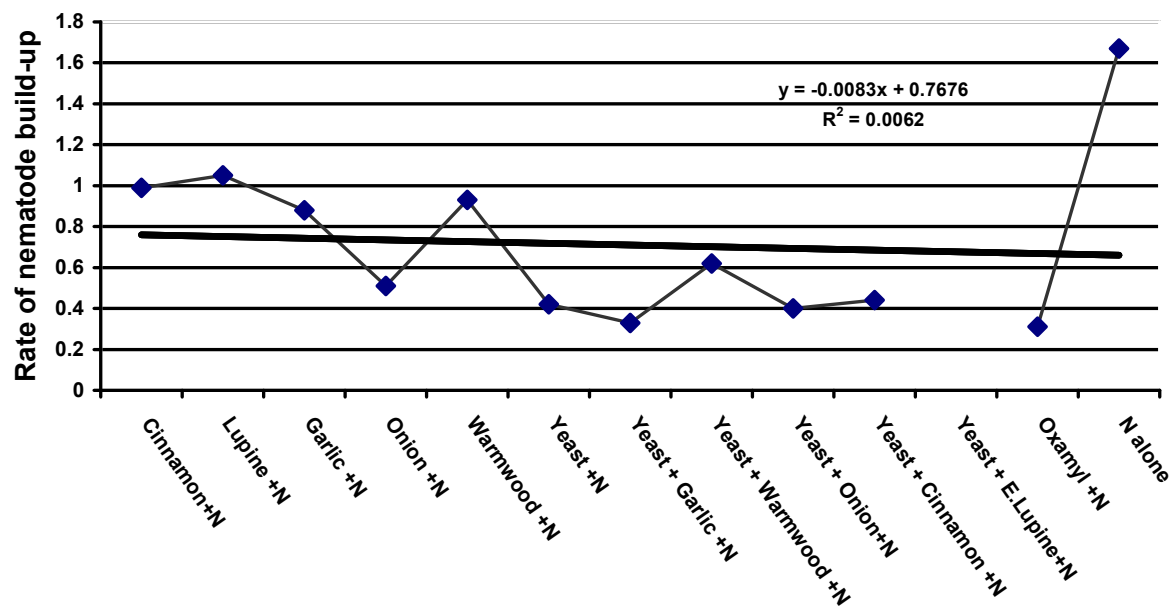

Treatments

Fig. (1): Rate of M. incognita build-up infecting broadbean cv. Sakha1 as influenced by five medicinal plant extracts and yeast extract as foliar spraying applications singly or followed with yeast extract in comparison with oxamyl under greenhouse condition at $19 \pm 3{ }^{\circ} \mathrm{C}$

Data presented in Table (3) show the influence of tested materials on nitrogen $(\mathrm{N})$, phosphorus $(\mathrm{P})$ and potassium $(\mathrm{K})$, organic matter $(\mathrm{O} . \mathrm{M})$, carbon $(\mathrm{C})$ concentrations as well as total chlorophyll and phenol contents of broadbean cv. Sakha 1 leaves infected with $M$. incognita under greenhouse condition at $19 \pm 3{ }^{\circ} \mathrm{C}$. It was evident that $\mathrm{N}, \mathrm{P}, \mathrm{K}, \mathrm{O}$. M. and $\mathrm{C}$ concentrations and total phenol content were significantly diminished, while that of total chlorophyll content sharply increased by nematode alone. All tested components either single or followed with yeast extract showed significant increase in $\mathrm{N}, \mathrm{P}$, and $\mathrm{K}$ concentrations and total phenol content as well as reduction values of total chlorophyll content comparing to nematode alone (Table 3). Of the tested single treatments, yeast extract as foliar spraying treatment achieved the highest increments values in nitrogen $(N)$, phosphorus $(\mathrm{P})$ and potassium $(\mathrm{K})$, organic matter (O. M), carbon (C) conc. and total phenol contents as well, since their values averaged 30.51, 10.22, 20.12, 64.8, 
37.7 and $52.05 \%$, respectively, comparing to nematode alone, whereas, wormwood gave the least concentrations of the same parameters, comparing to nematode alone (Table 3).

On the other hand, of the double treatments, cinnamon + yeast extracts accomplished the highest increase percentage values in nitrogen $(\mathrm{N})$, phosphorus $(\mathrm{P})$ and potassium $(\mathrm{K})$, organic matter $(\mathrm{O} . \mathrm{M})$ and carbon $(\mathrm{C})$ conc. that were amounted to $53.11,19.22,40.24,67.6$ and $39.3 \%$ respectively, comparing to nematode alone. It is worthy to note that all tested medicinal plant extracts followed by yeast extract as foliar spraying in this study, percentage increase values of total phenol were obviously recorded, where the binary treatment of garlic plus yeast extracts accomplished the maximum value in this respect, comparing to nematode alone (Table 3). Meanwhile, Oxamyl as a systemic nematicide significantly showed the highest increments value of total phenol (92.6\%) and gave also considerable values of $\mathrm{N}, \mathrm{P}$, and $\mathrm{K}$ concentrations that were amounted to $57.63,19.95$ and $41.42 \%$ accomplished with percentage reduction of total chlorophyll content (37.04\%) comparing to nematode alone, respectively. Results also showed that total chlorophyll contents in broad bean plant infected with $M$. incognita increased in plant treated with nematode without any applications with value of $1.59 \mathrm{mg} / \mathrm{g}$ Moreover, there was negatively correlations between the singly and concomitantly applications of the tested components regarding the reduction chlorophyll content , comparing to nematode alone, since their values were ranged from 37.92 and $49.62 \%$ for (cinnamon + yeast) and wormwood treatments, respectively, comparing to nematode alone. Moreover, $\mathrm{C} / \mathrm{N}$ ratio ranged from 16.3: 1 to 18.2:1 for yeast and wormwood as single treatments and from 14.5: 1 to 15.8:1 for (cinnamon + yeast) and (onion + yeast) binary treatments vs 24.51: 1 for nematode alone, respectively (Table 3).

Apparently, all tested treatments significantly improved broadbean plant growth characters. Moreover, all tested concomitant applications significantly gave better results than single one did. Of the single treatments, yeast extract showed the maximum values in ameliorating total plant length, total plant fresh weight and shoot dry weight followed by garlic extracts, onion extract and then cinnamon extract. Meanwhile, among the tested concomitant treatments, plant received garlic plus yeast extracts achieved the maximum results in ameliorating broadbean growth parameters, followed by onion plus yeast extracts. All tested materials obviously reduced nematode parameters to great extent. Among the single treatments, yeast extract overwhelmed other single treatments in suppressing nematode population $(74.7 \%)$, followed by onion extract $(69.4 \%)$. Moreover, pots received yeast extract alone achieved the maximum result in reducing this nematode character $(74.7 \%)$ and even exceeded some of the concomitant applications in suppressing final nematode population such as wormwood plus yeast extract $(63.1 \%)$, cinnamon + yeast $(73.8 \%)$ and lupine + yeast $(51.2 \%)$, respectively. Of the tested concomitant 
Table (2): Impact of five medicinal plant extracts and yesst extract as foliar sprajing applications singly a followed with yeast extract in comparison with oxamyl on development and reproduction of $M$. incognita infecting broadbean or. Sakha1 under greenhouse condition at $19 \pm 3^{\circ} \mathrm{C}$.

\begin{tabular}{|c|c|c|c|c|c|c|c|c|c|c|}
\hline \multirow[b]{2}{*}{ Treatments } & \multicolumn{3}{|c|}{ NNematode population in } & \multirow{2}{*}{$\begin{array}{c}\text { Final } \\
\text { population }\end{array}$} & \multirow{2}{*}{$\mathrm{RF}$} & \multirow[b]{2}{*}{ Red. \% } & \multirow{2}{*}{$\begin{array}{l}\text { No. of } \\
\text { galls }\end{array}$} & \multirow[b]{2}{*}{ RGI } & \multirow{2}{*}{$\begin{array}{c}\text { No. of } \\
\text { Eggmasses }\end{array}$} & \multirow[b]{2}{*}{ E } \\
\hline & Soil & \multicolumn{2}{|c|}{ Root } & & & & & & & \\
\hline Cinnamon & $960 \mathrm{C}$ & $29 \mathrm{c}$ & $10 \mathrm{c}$ & $999 \mathrm{c}$ & 0.99 & 40.3 & $18 \mathrm{~d}$ & 3 & $25 \mathrm{c}$ & 3 \\
\hline Lupine & $1000 \mathrm{~b}$ & $40 \mathrm{~b}$ & $15 b$ & $1055 \mathrm{~b}$ & 1.05 & 38.9 & $32 \mathrm{~b}$ & 4 & $30 \mathrm{~b}$ & 3 \\
\hline Garlic & $880 \mathrm{e}$ & $20 \mathrm{e}$ & $4 \mathrm{e}$ & $884 \mathrm{e}$ & 0.88 & 47.2 & $14 \mathrm{e}$ & 3 & $3 g$ & 2 \\
\hline Onion & $490 \mathrm{~h}$ & $18 \mathrm{f}$ & $4 \mathrm{e}$ & $512 \mathrm{~h}$ & 0.51 & 69.4 & $14 \mathrm{e}$ & 3 & $4 f$ & 2 \\
\hline \multirow[t]{2}{*}{ Warmwood } & $900 \mathrm{~d}$ & $22 d$ & $8 d$ & $930 \mathrm{~d}$ & 0.93 & 44.4 & $19 \mathrm{c}$ & 3 & $15 d$ & 3 \\
\hline & $406 \mathrm{j}$ & $12 \mathrm{~h}$ & $5 \mathrm{e}$ & 4231 & 0.42 & 74.7 & $12 f$ & 3 & $2 \mathrm{~h}$ & 1 \\
\hline Cinnamon + Yeast & $420 i$ & $15 g$ & $3 f$ & $438 \mathrm{i}$ & 0.44 & 73.8 & 11 & 3 & $1 \mathrm{i}$ & 1 \\
\hline Lupine + Yeast & $800 \mathrm{f}$ & $15 g$ & $2 g$ & $817 f$ & 0.82 & 51.2 & $18 d$ & 3 & $10 \mathrm{e}$ & 2 \\
\hline Garlic +Yesst & 3271 & $5 i$ & $2 g$ & $334 \mathrm{i}$ & 0.33 & 80.0 & $5 \mathrm{ji}$ & 2 & $0 \mathrm{j}$ & 0 \\
\hline Onion + Yeast & $390 \mathrm{k}$ & $12 \mathrm{~h}$ & $2 g$ & $404 \mathrm{~m}$ & 0.40 & 75.9 & $8 \mathrm{i}$ & 2 & $1 \mathrm{i}$ & 1 \\
\hline Wormwood + Yeast & $600 \mathrm{~g}$ & $17 f$ & $3 f$ & $620 \mathrm{~g}$ & 0.62 & 63.1 & $10 \mathrm{~g}$ & 3 & $1 \mathrm{i}$ & 1 \\
\hline Oxamyl & $300 \mathrm{~m}$ & $5 i$ & $2 g$ & $307 \pi$ & 0.31 & 81.7 & $4 j$ & 1 & $0 \mathrm{j}$ & 0 \\
\hline $\mathrm{N}$ alone & $1500 \mathrm{a}$ & $108 \mathrm{a}$ & $68 \mathrm{a}$ & $1874 a$ & 1.67 & - & $110 \mathrm{~g}$ & 5 & $100 \mathrm{a}$ & 5 \\
\hline
\end{tabular}

"- Esch value is a mean of four replicates. Mean values in each column followed by the $s$ ame letter(s) did not differ at $P<0.05$ sccording to Duncari's multiple range test. 
applications, pots received garlic extract followed with yeast extract followed by yeast extract as foliar spraying application, overwhelmed other integrated treatments. All tested components either single or followed with yeast extract showed significant increase in $\mathrm{N}, \mathrm{P}$, and $\mathrm{K}$ concentrations and total phenol content as well as reduction values of total chlorophyll content comparing to nematode alone. These findings were supported by those reported by Kesba (2010) in respect to treatments of humic and fulvic acids that significantly improved the levels of nonenzymatic antioxidants molecules including total phenol in the roots infected grape rootstocks with Rotylenchulus reniformis or $T$. semipenetrans, especially at the higher concentration of the organic acids. Increasing levels of total phenol may serve as defence compounds against pathogens (Kosugie, 1969). Oxamyl as a systemic nematicide at full recommended dose with high value of ammonium $(57.6 \%)$, low value of phosphorus (19.9) and a moderate value of potassium $(41.4 \%)$ gave very few galls (4), females (5) and eggmasses (zero) number of $M$. incognita on broadbean cv. Sakha1 plant, respectively, where a similar trend was noticed with the binary treatment containg garlic followed by yeast extract as foliar spraying in this study. These findings are in accordance with those reported by AlGhnam (2011) in respect with the influence of four tested bio agents, Ditera, Bio arc, Bio-zeid and protecto singly or mixed plus oxamyl at half dose on $N, P, K$ and total phenol in sour-orange infected with $T$. semipenetrans that showed significant increase of these elements and total phenol and reduction of total chlorophyll comparing to nematode alone. Moreover, the applications of yeast alone or sprayed after with either garlic or cinnamon gave the highest percentage increase values of ammonium $(\mathrm{N})$ that of averaged $30.51 \%$ or $50.85 \%$ or $53.11 \%$ with $\mathrm{C} / \mathrm{N}$ ratio of 16.3:1 or $14.7: 1$ or $14.5: 1$ vs 24.5 for nematode alone. These findings are in agreement with those reported by El-Sherif et al. (2012) in respect to the applications of either yeast or salicylic acid plus Calcium $200 \mathrm{mg} / \mathrm{l}$ that gave the highest percentage increase values of ammonium $(N)$ with $C / N$ ratio of 18.6:1 and 18.8:1 vs 28.0:1 for nematode alone. These $\mathrm{C}$ : $\mathrm{N}$ ratio of those treatments of the present work agreed with those of Miller and Donahue (1990) who stated that organic residues with $\mathrm{C}: \mathrm{N}$ ratio $20: 1$ or narrow have sufficient nitrogen to supply the decomposing microorganism and also to release for plant use.

Undoubtedly, the biotic factors used in this investigation as tool for M. incognita management on broadbean cv. Sakha 1 plant through foliar spray single or double application containing such extract followed by yeast extracts on broadbean succeeded to generate a sort of inducing resistance in a susceptible host plant against such pathogenic nematode, since certain application i.e. garlic + yeast extracts as applied in this study showed very few number of galls, females and zero eggmasses on root system of broadbean cv. Sakha 1 plant infected with M. incognita under greenhouse conditions, a phenomenon which can be a novel trend for such pathogenic nematode control. However, more research is needed for such trend under field conditions. 


\section{References}

Al-Ghnam, Heba, A. A. (2011). Integrated management of citrus nematode, Tylenchulus semipenetrans. Ph. D. Thesis, Fac. Agric. Mans Univ.155pp.

Barker, K. R.; G. A. Pederson and G. L. Windham (1998). Soybean. Plant and nematode interactions, 317-333.

Byrd, D.W.; T. Kirkpatrick and K. Barker (1983). An improved technique for clearing and staining plant tissues for detection nematodes. J. Nematol., 15 (3): 142-143.

Duncan, D.B. (1955). Multiple range and multiple, F-test. Biometrics, 11: 1-42.

Duponnois, R.; A.M. Baker and T. Mateille (1999). Benificial effects of Enterobacter cloacae and Pseudomonas mendocina for biocontrol of Meloidogyne incognita with the endospore-forming bacterium, Pasteuria penetrans. Nematol., 1: 95-101.

EI-Sherif; A. G.; O. A. Nassar; A. R. Refaei; M. E. El-Nagar and Marwa M. Shalaby (2012). Biochemical response of foliar spraying yeast or salicylic acid mixed with certain inorganic fertilizers in tomato plants infected with Meloidogyne incognita under greenhouse conditions. Egypt. J. Agronematol., 11(2):309-319.

Goodey, J.B. (1957). Laboratory methods for work with plant and soil nematodes. Tech. Bull. No. 2. Min. Agric. Fish Ed. London, 47 pp.

Gomez, K. A. and A. A. Gomez (1984). Statistical procedures for Agricultures Research, $2^{\text {nd }}$ ed., June Willy \& Sons Inc. New York.

Hojat, A. A., R. Segers and J. Coosemans (1998). Biocontrol of Heterodera schachtii using combinations of the sterile fungus, StFCH1-I, Embellisia chlamydospora and Verticillium chlamydosporium. Nematologica, 44: 345-355.

Hussey, R. S. and K. R. Baker (1973). A comparison of methods of collecting inocula of Meloidogyne spp. Including a new technique. PI. Dis. Repte., 57: 1025-1028.

Jakson, M.L. (1967). Soil chemical analysis. Prentice. Hall of India, New Delhi. $498 \mathrm{pp}$.

Kesba, H. H. (2010). Biochemical alterations in grape infected with three phytonematode species with emphasis on root-knot nematode control. Egyptian J. Agronematol., 9(2): 116-131. 
Khan, M.R. (2007). Prospects of microbial control of root-knot nematodes infecting vegetable crops, In: Biotechnology, Plant Health Management (N. Sharma, H.B. Singh, ed.). International Book Distributing Co., Lucknow, India, 643665.

Kosugie, T. (1969). The role of phenols in host response to infection. Annual Review Phytopathol., 7: 195-222.

Miller, R.W. and R.L. Donahue (1990). Organic matter and container media. Soils: An Introduction to Soils and Plant Growth. $6^{\text {th }}(\mathrm{Ed})$. Prentice Hall, Inc; Englewood Cliffs, N.J. U.S.A. Pp.181-225.

Taylor, A. L. and Sasser, J. N. (1978).Biology identification and control of root-knot nematode(Meloidogyne spp.) Raleigh: North Carolina state Univ. Graphics.

Taylor, A. L., V. H. Dropkin, and G. C. Martin, (1955). Perineal patterns of rootknot nematodes. Phytopathology 45:26-34.

Wellburn, A.R. and H. Lichtenthaler (1984). Formula and program to determine total carotenoids and chlorophylls $A$ and $B$ of leaf extracts in different solvents. In: Advances in photosynthesis Research, vol. 2 (ed. By C. Sybesma), pp. 9-12. martinus Nijh off/dry W. Junk. The Hague, Boston, Lancaster. 


\section{الملخص العربي}

\section{المكافحة المتكاملة لنيماتودا تعقد الجذور علي نبات الفول البلدي برش بعض مستخلصات النباتات الطبية العطرية منفردة أو مزدوجة مع الخميرة تحت تأثير الصوبة الزراعية}

أحمد جمال الثريف*، أحمد حماد نور الدين** ، سمير برهام جاد*، حسام عبد التواب النحاس

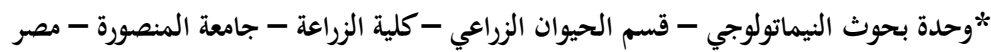

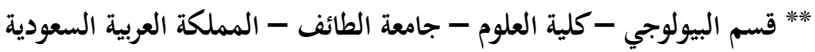

في هذه التجربة تم دراسة تأثير رش محاليل خمسة من المساحيق الجافة لنباتات البصل (قواعد الأوراق

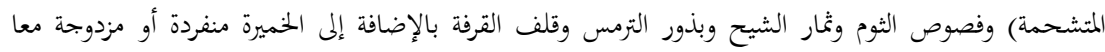

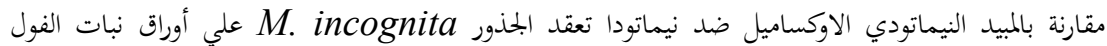

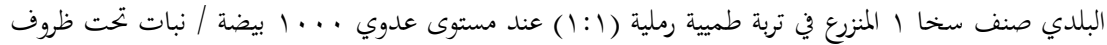

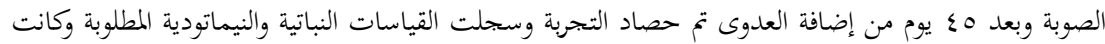

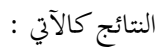
1. أشارت النتائج إلى أن جميع المعاملات المختبرة أدت إلى تحسن كبير في نمو النبات وخفض معدل تكاثر النيماتودا ، وكذلك كانت نتائج المعاملات المزدوجة أفضل من المعاملات الفرات الفردية.

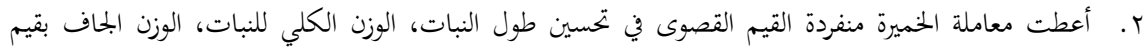

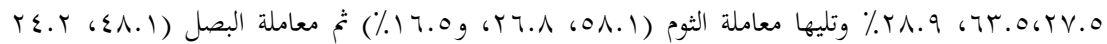

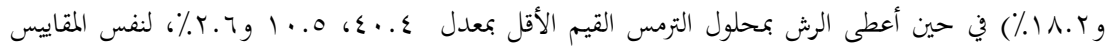
النباتية على التوالي.

r. احتلت المعاملة المزدوجة للرش (الثوم + الخميرة) المركز الأول بين المعاملات المزدوجة في تحقيق أقصى معدلات

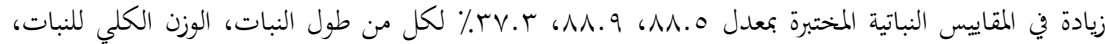

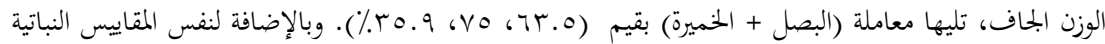
علي التوالي.

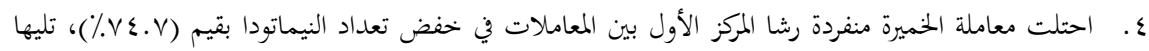

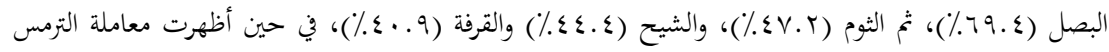

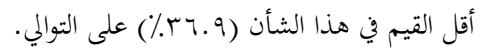

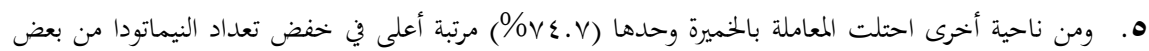

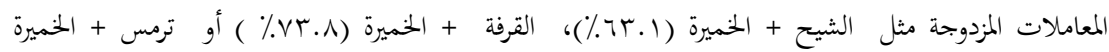

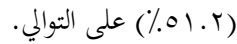

4. الخفضت تركيزات النتروجين (N) والفسفور (P) والبوتاسيم (K) والمادة العضوية، في حين ارتفع المتوى الكلي

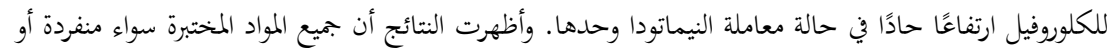

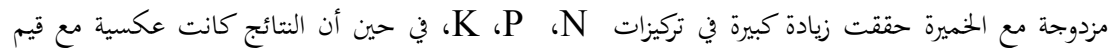
المحتوى الكلي للكلوروفيل والفينول مقارنة بالنيماتودا . 